\title{
Academic Fraud Behaviour of Accounting Students: The Investigation Using Fraud Pentagon Theory
}

\author{
Octavia Lhaksmi Pramudyastuti ${ }^{1}$, Ghina Fitri Ariesta Susilo ${ }^{2}$, Danar Putri Miranda ${ }^{3}$ \\ \{octaviaovi@untidar.ac.id ${ }^{1}$, ghinafitri.ariesta@untidar.ac.id ${ }^{2}$, danarputri82@gmail.com ${ }^{3}$ \}
}

Faculty of Economics, Universitas Tidar. Jalan Kapten Suparman 39, Magelang, Indonesia ${ }^{123}$

\begin{abstract}
Academic fraud is a phenomenon that occurs in the education field. It happens in every level including in the education of prospective accountant students. That phenomenon contrasts with the purpose of education, which is to produce professional accountants and ethical behaviour. This research aims to investigate the fraud behaviour in academic environment that is done by the university students. To investigate the fraud, this research used fraud pentagon theory. This study is a qualitative research with using case study approach. The data is collected by observing and interviewing ten accounting students from two universities in Magelang. The result of this study shown that academic fraud can occur in every universities. This act of academic fraud by students was caused by several elements based on Fraud Pentagon Theory Those elements are pressure, opportunity, rationalization, competence, and arrogance of academic fraud perpetrators.
\end{abstract}

Keywords: Academic Fraud; Behaviour; Fraud Pentagon Theory; Accounting Students; Magelang.

\section{Introduction}

Accountants have an important role in a business process. One of the roles of an accountant is the preparation of the entity's financial statements which are needed by various parties for decision making. This requires that all information contained in the financial statements is informative, valid, and reliable. The quality of these financial statements is highly dependent on the professionalism and ethics of the maker, namely the accountant. An understanding of the professionalism and ethics of the accountant profession is obtained from the world of education. This was revealed by Puspitarini and Kusumawati (2011) which stated that the world of accounting education has a considerable influence on the ethical behaviour of an accountant [1].

Accounting education must be able to create professional accountants in line with the development of today's business world. It takes a qualified accounting education process to be able to realize the ideals in shaping the character of a professional and ethical accountant. The Indonesian government as the highest regulator for education policy regulates the character building in every educational process. 
Currently, the Indonesian government determines various policies that are implemented in the accountant education process for the sake of forming the character of the accountants themselves. Government policies regarding the education system are in fact contrary to the phenomena that occur in the world of education, one of which is academic fraud. Murdiansyah et al (2017) stated that fraudulent practices are still often found and occur in educational settings including in universities [2].

Sasongko et al (2019) states that most students think that education in a university is only a steppingstone to getting a job. They also assumed that graduates with low GPA would find it difficult to get a job [3]. In general, students focus only on their final grade, not on the process. This assumption is what causes students to commit many acts of academic fraud.

Forms of academic fraud that are commonly practiced by students include cheating, taking small notes during exams, copying peer answers, searching for answers via the internet without paraphrasing, and using gadgets during exams. Some cases also show plagiarism in students' articles and final assignments. The worst effects of plagiarism usually result in students failing to earn bachelor's degrees.

During concern over the phenomenon of academic fraud, various researchers conducted research that analysed the causes of academic fraud by students. Becker et al (2006) examined the fraud triangle theory to predict academic fraud in business students. Becker's research shows that the three elements of the fraud triangle (pressure, opportunity, and rationalization) influence student fraud behaviour [4]. The study only uses three elements in the fraud triangle. Azzahroh et al (2020) conducted a study on the effect of self-efficacy and fraud diamonds on the fraud behaviour of accounting students [5]. The elements that cause fraud in this study consist of pressure, opportunity, rationalization, and ability. The results showed that simultaneously self-efficacy and diamond fraud influenced fraud behaviour, while partially only the opportunity and ability variables influenced students' fraud behaviour.

This research tries to accommodate the discovery of new theories regarding the five causes of fraud, namely the fraud pentagon theory. This theory was discovered by Crowe Horwath LLP (2010), a bona fide public accounting firm in America. Crowe argues that the fraud triangle has morphed into the fraud pentagon [6]. Crowe's pentagon fraud describes five things that make a person commit fraud. The five elements include pressure, opportunity, rationalization, competence, and arrogance. Crowe argues that fraud is done not only because of economic factors but also factors of ego, status, and pride.

For the discovery of this new theory, researchers want to investigate the causes of academic fraud behaviour among accounting students in Magelang City based on the Pentagon's Fraud Dimensions, namely Pressure, Opportunity, Rationalization, Competence, and Arrogance and identify problem-solving solutions to reduce academic fraud committed by students based on dimensions of Pentagon fraud. 


\subsection{Literature Review}

\section{Academic Fraud Behaviour}

The Indonesian Public Accountants Association (2013) states that fraud or fraud is an intentional act by one or more individuals in management or those responsible for governance, employees who involve the use of deception to gain an unfair advantage or break the law [7]. Fraudulent behaviour does not only occur in the profit-oriented business sector, but also in the non-profit sector, one of which is educational institutions. One example of non-economic fraud in an educational institution is academic fraud behaviour.

Academic fraud is an act that violates the character education rules regarding honesty. Many students commit academic fraud to get a good GPA. They do not realize that this action violates ethics. An educational process is not only output oriented but also process oriented. This is because a learning is obtained from the process of achieving something.

Colby (2006) states that at Arizona State University the category of academic fraud is divided into five categories [8], those are:
a. Plagiarism
b. Falsification of data, for example making scientific data which is fictitious data.
c. The dual task is to submit the same two papers to two different classes without the permission of the lecturer.
d. Cheating on exams
e. Negative cooperation

\section{Pentagon Fraud Theory}

In 2010, a public accounting firm in America, Crowe Horwath LLP found a new theory regarding the causes of fraud. The development of this theory is because Cressey's fraud triangle theory is deemed irrelevant to current conditions. According to Fraud Pentagon Theory, there are five elements that underlie someone committing fraud. These elements included: pressure, opportunity, rationalization, competence, and arrogance.

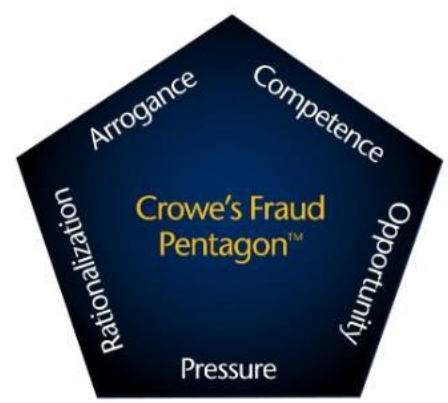

Fig 1. Crowe's Fraud Pentagon 
The newest element added to Crowe's Fraud Pentagon is Arrogance. Pramudyastuti (2020) argues that Fraud is not always related to the search for material assets but can be due to the search for achievement or prestige [9]. The addition of aspects of ability and arrogance by Crowe (2010) is a result of his observations on employees who have the ability to ignore and fool the internal control system as its fourth aspect, namely ability or capability [6]. Meanwhile, he explained the arrogance aspect of the assumption that employees who commit fraud will not have a problem with their actions because they feel that they are far superior to the existing system.

\section{Methodology}

This research is a qualitative research with a case study approach. The data is collected by using observations and interviews. This study is the result of an investigation into the factors that cause student academic fraud at universities in the city of Magelang.

The data for this study were obtained by observing and interviewing 10 respondents. It consists of five students in 7th semester from Accounting Department of Universitas Muhammadiyah Magelang and five students in 7th semester from Accounting Department of Universitas Tidar. Researchers want to investigate students' perceptions about the causes of their academic fraud behaviour based on the Pentagon's Fraud Theory Concept and input from respondents for an effective learning process to minimize academic fraud behaviour.

\section{Finding and Discussion}

This study uses Crowe's Fraud Pentagon which is the development of previous findings, namely the Fraud Triangle Theory and Fraud Diamond Theory. The difference from the Fraud Pentagon Theory from the previous theories is the addition of a fifth element, namely the arrogance of the fraudsters. Researchers use aspects of pressure, opportunity, rationalization, competence, and arrogance as aspects that encourage accounting students to commit academic fraud.

\section{Academic Fraud}

The results of interviews and observations regarding academic fraud behaviour are shown in table

1 below. 
Tabel 1. Interview results of academic fraud behaviour

\begin{tabular}{lccccc}
\hline & Plagi & Data & Task & F & Incorrect \\
Responden & V & V & - & V & V \\
Responden & V & V & - & V & V \\
Responden & V & - & - & V & V \\
Responden & V & - & - & V & V \\
Responden & V & - & - & V & V \\
Responden & V & - & - & V & V \\
Responden & V & V & - & V & V \\
Responden & V & V & - & V & V \\
Responden & V & - & - & V & V \\
Responden & V & - & & &
\end{tabular}

$\mathrm{V}$ = have done

- $=$ never did

Table 1 shows that all respondents have committed academic fraud behaviour. Three types of academic fraud are often carried out, namely plagiarism, cheating and wrong cooperation. For data falsification, only 3 respondents had done it.

\section{Academic Pressure and Fraud}

Pressure is an impulse that creates unpleasant conditions. Pressure can have a positive or negative effect. The worst effect of pressure is making people do things that are not good because they are mentally disturbed by something that makes them stressful. Albrecht (2012) states that pressure comes from feelings that make someone commit fraudulent behaviour [10]. This pressure can come from the immediate environment (parents and siblings) or the external environment (friends or neighbours). Albresct also describes academic fraud behaviour as a response that arises because there are too many demands and tasks that must be done by students. Pressure makes people do unkind things because they are mentally distracted by something that stresses them out.

The results of the study stated that respondents emphasized that pressure could make someone commit fraud. As many as 6 out of 10 respondents stated that their fraud was caused by pressure from outside intervention. Pressure that comes from outside can be in the form of parents' demands for academic achievement that is too high but does not provide understanding to children, demands to be able to finish college and graduate on time, campus demands that come from academic regulations, competition between students in academics (prestige) and the requirements for seeking educational scholarships. There were several respondents who admitted that they were pressured to seek scholarships because of the intense competition that made them commit fraud.

The pressure factor states that academic fraud behaviour can be started from the existence of strong pressure or encouragement from various sources. One type of pressure can be a strong reason for a student to commit academic fraud, so that students who experience various pressures have the potential to commit academic fraud. The solution that can be offered is to manage the condition or mental health of students by means of counselling from lecturers or other parties. 


\section{Opportunity and Academic Fraud}

Opportunity is a situation where someone gets lucky or something that is profitable for him. Based on the results of interviews with all respondents, it was concluded that the element of opportunity that caused academic fraud was caused by a weakness in the internal control system in the learning system. Some of the arguments found by students regarding the weaknesses of the assessment and learning system, among others: a weak examination system, indecisive application of sanctions, and lecturers who were not serious in correcting questions or assignments.

The most frequent acts of fraud by students during exams were fraud and carrying small notes that were placed in hidden places. Students often repeat this action every time they take an exam. Some respondents said that the existing surveillance system provides concessions for test takers to engage in academic fraud behaviour.

Four Respondents stated that another opportunity that strengthens the act of academic fraud is the weak system of guarding and supervision of the examination supervisor. The supervisory team sometimes does not pay attention to the exam participants and has their own activities so that students can easily commit to do fraud. In the learning process, sometimes there are lecturers who are not serious about researching students' work and answers, thus opening opportunities for students to commit academic fraud in the form of plagiarism. Where plagiarism is the biggest crime in the world of academia.

\section{Rationalization and Academic Fraud}

There were various justifications conveyed by respondents regarding their reasons for committing academic fraud. A classic rationalization conveyed by most respondents is that their academic fraud behaviour is a positive effort to increase the credibility of the educational institution itself. It is ironic that this rationalization is true, but indeed some educational rules or policies require a condition that is fixated on results not on processes.

Some respondents stated that their fraud would be tolerated by their close friends because it was an effort to increase their Achievement Index. There are also those who argue that the incident was the result of a weak education system, so that they cannot be blamed. One rationalization for fraud that many respondents conveyed is that there are unclear instructions when giving assignments from lecturers making students cooperate while doing assignments.

The next rationalization is about lecturers who are not serious in providing material, so that students have difficulty understanding the material. Most respondents admitted that they were not ready to accept the material, so they looked for references that did not match the main material. When getting the exam questions, the student could not understand the correct answer, so there was a desire to commit academic fraud.

The last rationalization is the reason for the short time to complete the assignment and exam questions. Students often do not realize that assignments and exam questions are designed to test their ability to manage time. Rationalization reinforces another aspect of the Pentagon's Fraud Theory. Without rationalization, fraud will never be committed because fraud is against the ethical understanding of the perpetrator. 


\section{Academic Competence and Fraud}

Competence referred to in this case is the ability to analyse the opportunities to commit fraud. This ability is then accompanied by information about system weaknesses and other opportunities so that students feel capable of fraud. As many as 7 out of 10 respondents stated that they felt they had the ability to cheat safely. The fraud strategies taken by the respondents varied, among others, by exchanging answers with other classes that had already carried out tests or exams. Another strategy is to invite friends to cooperate and exchange answers

Wolfe and Hermanson (2004) concluded that without the ability or competence of the perpetrator, fraudulent acts will not occur [11]. Crowe (2010) states that competence ignores, deceives, and makes students too confident to commit fraud [6]. This is in line with the answers of respondents who stated that they needed expertise that could seize opportunities to commit acts of fraud

Several respondents added that the basic competencies possessed in fraud are the ability to invite and convince friends and the ability to analyse the types of lecturers in teaching and provide academic assessments to students. Through this analysis, students can determine what fraud can be done without creating a high risk of being caught.

\section{Arrogance and Academic Frau}

Arrogance is arrogance or arrogance that arises from within a person. The element of actor arrogance is the last aspect in Crowe's Fraud Pentagon. Crowe (2010) states that the arrogance of an offender encourages self-confidence and courage to cheat [6]

Arrogance as the last aspect put forward by Crowe (2010) is an aspect that respondents assessed as driving student academic fraud behaviour [6]. This is due to the prestige they have to the arrogance of those who think they can be freed from sanctions due to the violations they have committed

Five out of ten respondents claim to have arrogance that drives them to commit academic fraud. This happens because they think that the existing system is unable to provide a deterrent effect for them. Respondents also thought that fraud was not an easy matter to do so they felt great if they were able to do it. This proves that arrogance is an aspect that has a significant effect on student academic fraud.

\section{Academic Fraud Prevention Measures Based on Fraud Pentagon Theory}

Academic fraud is behaviour that violates various aspects, not only violating academic regulations, but also violating ethics and morals. Dishonesty that starts early is very dangerous, especially lies.

committed in the world of education are very destructive to morals. The educational process that prepares prospective accountants to be able to apply their knowledge in a professional manner is used as a venue for fraud training. This is an irony and must be followed up immediately. The act of academic fraud committed by accounting students is proof that the education system for accountants must be addressed immediately. Various examples of fraud committed by accountants are clear evidence that character education must be prioritized.

As the top of education, higher education institutions need to take seriously the fraud behaviour that occurs in academic activities in the campus education environment. 
Several things can be done to be able to overcome, minimize, and prevent fraud by students. Some things that can be done regarding these five elements are as follows:

\section{Pressure}

Based on observations, the researchers stated that pressure was the main element driving academic fraud. The stress element that comes from the psychological side, causes an impact on someone's irrational and moral behaviour. This pressure element causes a person to behave so that he no longer feels pressure. Several things that can be done as a preventive measure for this aspect of pressure are by providing guidance to students intensively, providing activities that are able to prevent students from committing fraud. Institutions can hold seminars on psychology and provide spiritual and mental guidance so that good morals continue to be built (balance IQ, EQ, SQ, AQ).

\section{Opportunity}

The opportunity element has a close relationship with the internal control system. If an educational institution has a good internal control system, fraud can be anticipated and minimized. In a discussion of the relationship between academic fraud and the aspect of opportunity, it can be concluded that academic fraud behaviour occurs due to weaknesses in the internal control system. Several stages that can be carried out as an effort to improve the internal control system in a higher education institution are:

a. Improving the examination guard system, can be done with an observation system via CCTV, b. Mapped exam rooms well and small groups,

c. Regular monitoring of the lecturer learning process, whether in class learning, routine assignments, or giving grades to students.

d. Validate each exam question,

e. Monitoring and evaluation of academic regulations, f. Giving clear task instructions

g. Enforcement of sanctions for academic fraud violations

\section{Rationalization}

Researchers reveal that the rationalization aspect is based on sociological and cultural factors. A respondent who has had a previous history of fraud has influenced other students to participate in fraud. The justification that has been done and discovered since school has led to higher rationalization that is believed by students. Students increasingly feel that fraud is normal and does not have a negative impact on themselves or others. This is a calculation that only strict sanctions can provide a deterrent effect and alert students to stop the academic fraud behaviour.

\section{Competency}

The competency aspect is an aspect that affects the behaviour of academic fraud by students. This aspect then becomes the basis for committing fraud because of the belief that their actions will not be detected. The key to reducing academic fraud based on the competency element is the improvement of the supervisory system and the internal control system by the institution so that the gap to cheat is getting smaller. Lecturers also need to update the types of questions and assignments so that students no longer underestimate the grades they will get. 


\begin{abstract}
Arrogancy
As a new element, Arrogance has a major influence on academic fraud by students. Arrogance as a mental aspect ignores ethics and does not care about applicable rules. Students consider themselves great because they commit acts of fraud and will keep repeating it again and feel proud of it. To address academic fraud behaviour based on a review of arrogance elements, higher education institutions need to create a conducive academic atmosphere. This is reinforced by the affirmation of sanctions for perpetrators of academic fraud. Another preventive measure can be done by instilling ethical values in the academic process through additional activities outside of lectures. Students also need more appreciation for their achievements or achievements.
\end{abstract}

\title{
4 Conclusion
}

Based on the investigations that have been carried out, it can be concluded that the act of accounting student academic fraud is a phenomenon that occurs in every college. This act of academic fraud was caused by several elements. The new theory about fraud, namely the Fraud Pentagon Theory, explains that there are five causes of student fraud behaviour. The five elements include: pressure, opportunity, rationalization, competence, and arrogance of academic fraud perpetrators.

The results of the first investigation proved that students committed academic fraud caused by various pressures, especially external pressure to achieve a good Achievement Index score. From the pressure they get, students will see the opportunities that exist, namely, to take advantage of the looseness of the learning system, both the examination supervision system and lecturer regulations. To be able to commit fraud without being burdened by ethical conflicts, students need to justify or rationalize their fraudulent behaviour. Then the competency element is the reason for a student to commit academic fraud with confidence and courage. Without competence, a student will find it difficult to find the gaps and weaknesses of each learning system so that he will not succeed in realizing his academic fraud plan. The last element is arrogance, where it is stated that sometimes the perpetrator of fraud is not only fraud to increase value but because of arrogance or arrogance.

Academic fraud is a phenomenon that is rife in universities, ranging from academic fraud in the form of plagiarism or simply fraud. This has the potential to give birth to professional accountants who are unethical and justify various ways to achieve personal gain. There are several ways that can be done to prevent and minimize student academic fraud, namely: academic guidance, improvement of the learning system to the internal control system of the institution, giving strict sanctions to students and improving the quality and monitoring of examinations and finally providing activities regarding the balance of IQ, EQ intelligence, SQ, and AQ to students.

This research is surely having some limitations. The limitations of this study are the limited number of respondents who make this study not yet representing the opinions of every accounting student. The generalization of this study is also limited as we only observed a view number of students in two universities. We hope that further 
research be able to provide new theories that are more relevant and accurate to identify the causes of students committing academic fraud.

\section{References}

[1]. Puspitarini D, Kusumawati F. Faktor-Faktor yang Mempengaruhi Minat Mahasiswa Mengikuti Pendidikan Profesi Akuntansi (PPAk). Jurnal Investasi. 2011. Vol. 7 No.1: 46-63.

[2]. Murdiansyah I, Sudarma M, Nurkholis. Pengaruh Dimensi Fraud Diamond terhadap Perilaku Kecurangan Akademik (Studi Empiris pada Mahasiswa Magister Akuntansi Universitas Brawijaya). Jurnal Akuntansi Aktual. 2017. Vol. 4, No. 2: 121-133.

[3]. Sasongko N, Hasyim MN, Fernandez D. Analysis of Behavioral Factors that Cause Student Academic Fraud.The Journal of Social Sciences Research. 2019. Vol. 5, Issue. 3: 830-837.

[4]. Becker D, Connoly J, Lentz P, Morrison J. Academi of Educational Leadership Journal. 2006. Vol 10 No 1.

[5]. Azzahroh F, Suhendro, Fajri RN. The Effect of Self Efficacy and Fraud diamond on Fraudulent Behavior Academic Accounting Students. Journal of Business, Management, and Accounting. 2020. Vol 2. Issue 1:116-122.

[6]. Crowe Howarth LLP. 2010. IIA Practice Guide: Fraud and Internal Audit. Retrieved from http://aiba- us.org/wpcontent/uploads/2011/04/20100922AIBA Fraud.pdf

[7]. Indonesian Public Accountants Association. 2013. Standar Profesi Akuntan Publik, www.iapi.or.id

[8]. Colby. Cheating: What is it. (Online). 2006.http://clas.asu.edu/, accessed in 20 Juni 2020.

[9]. Pramudyastuti OL, Fatimah AN, Wilujeng DS. Perilaku Kecurangan Akademik Mahasiswa Akuntansi: Investigasi Dimensi Fraud Diamond. Journal of Economic, Management, Accounting and Technology (JEMATech). 2020. Vol. 3, No.2. DOI: https://doi.org/10.32500/jematech.v3i2.13001.

[10]. Albrecht WS, Albrecht CO, Albrecht CC, Zimbelman MF. Fraud Examination, Fifth Editon. Boston: Cengage Learning; 2012. 672 p.

[11]. Wolfe DT, Hermanson DR. 2004. The Fraud Diamond: Considering The Four Element Of Fraud. The CPA Journal. 2004.38-42. 